DE ECONOMIST 158, NO. 4, 2010

\title{
RETIREMENT OF OLDER WORKERS AND EMPLOYMENT OF THE YOUNG
}

\author{
BY \\ ADRIAAN KALWIJ*,**, ARIE KAPTEYN ${ }^{* * *}$, KLAAS DE VOS****
}

\begin{abstract}
Summary
Policy makers have often argued that an additional benefit of facilitating early retirement is that it creates employment for the young. This may happen if older and younger workers are substitutes. Nowadays policies are aimed at increasing employment of older people to counter the economic consequences of an aging population. Opponents of such policies argue that these will adversely affect youth employment. This paper revisits the nexus between employment of older and younger workers, if only to put any concerns for adverse effects of later retirement on youth employment to rest. To empirically investigate this issue we estimate a dynamic model of employment of the young, prime age and old people using panel data of 22 OECD countries over the time period 1960-2008. Our empirical analysis does not support the hypothesis that employment of the young and old are substitutes and finds some minor complementarities. This suggests that encouraging later retirement will have no adverse effect on youth employment.
\end{abstract}

Key words: youth employment, retirement, panel data

\section{INTRODUCTION}

Social security programs create disincentives for continued work at older ages in many OECD countries (Gruber and Wise 2004). During the 1980s and early 1990 s increasingly more generous early retirement schemes were in place and, arguably, attributed to the falling male employment rates for the older population (see Figure 1). ${ }^{1}$ Policy makers have often argued that an additional benefit of facilitating early retirement is that it creates employment for the young (Gruber and Wise 2010). Older people who retire and leave the labour force release jobs for younger people. This has been a very popular

\footnotetext{
*Corresponding author: Utrecht University School of Economics, Utrecht, The Netherlands, e-mail: a.s.kalwij@uu.nl

**Network for Studies on Pensions, Aging and Retirement (Netspar), The Netherlands, URL: www.netspar.nl

***RAND, Santa Monica, CA, USA.

**** CentERdata, Tilburg University, Tilburg, The Netherlands.
}

1 Figure 2 shows a different pattern for the employment rate of older women, presumably reflecting a cohort effect whereby the more recent cohorts have a higher participation rate than the older cohorts. 


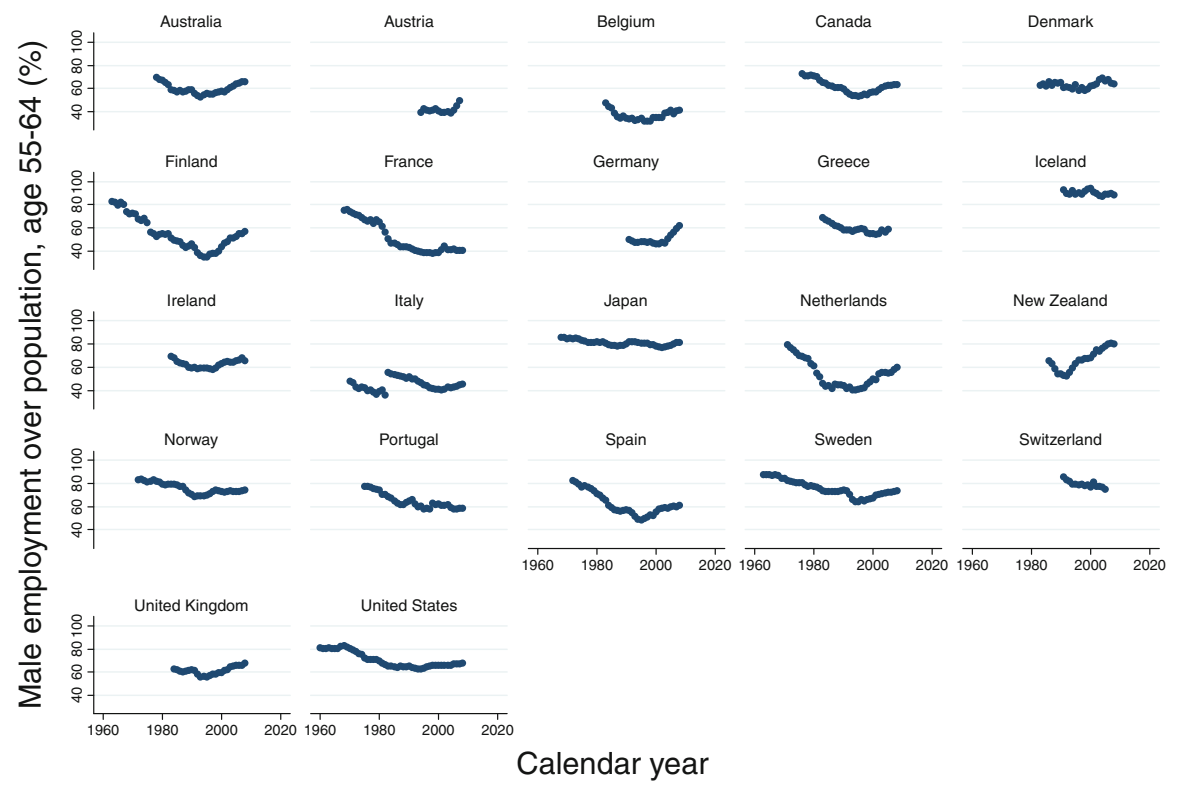

Figure 1 - Employment rate of older males, aged 55-64. A selection of 22 OECD countries

argument in the 1970s and 1980s when youth unemployment was rising (see Figure 3). The validity of this argument is mainly based on the two assumptions that there is a fixed amount of work to be done in the economy, which is not affected by older workers leaving the labour force, and that older and younger workers are substitutes. ${ }^{2}$

Concerning the former assumption that there is a fixed amount of work to be done, economic theory suggests that this is a very special assumption indeed and it is thus often referred to as the lump of labour fallacy. ${ }^{3}$ Wage costs may increase when, for instance, the demand for younger workers increases or early retirement schemes are financed through payroll taxes (see, e.g., Van Dalen and Henkens 2002). This, in turn, will reduce the total demand for labour and the effect of early retirement on employment may be negative even when older and younger workers are substitutes. The empirical

2 There are many definitions of elasticities of substitution in the literature. Here we define production factors as substitutes somewhat informally as the case where an exogenous increase in the supply of one factor decreases the demand for the other factor. Similarly, we define factors to be complements if the increase in supply of one factor leads to an increase in the demand for the other factor.

3 Empirical evidence suggests that worksharing policies during the 1980s and 1990s were a rather ineffective instrument for reducing unemployment as it resulted in higher real wage rates and, consequently, reduced total employment (see Kapteyn et al. 2004). 


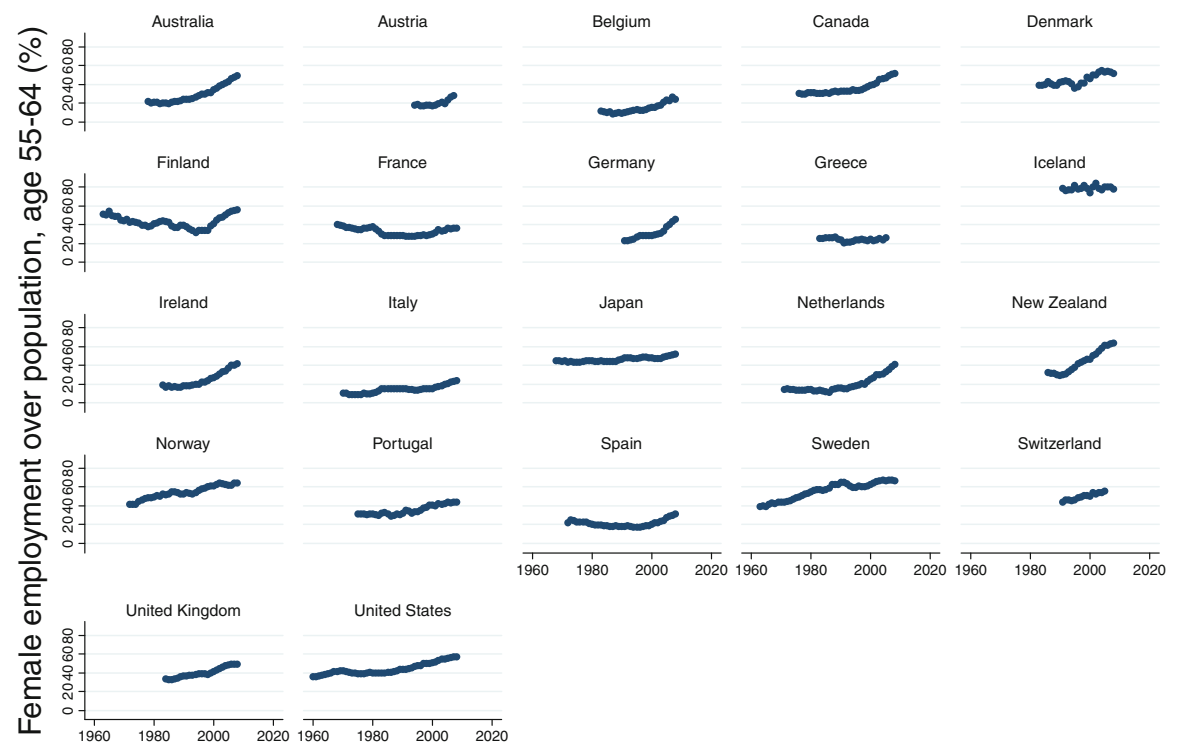

\section{Calendar year}

Figure 2 - Employment rate of older females, aged 55-64. A selection of 22 OECD countries

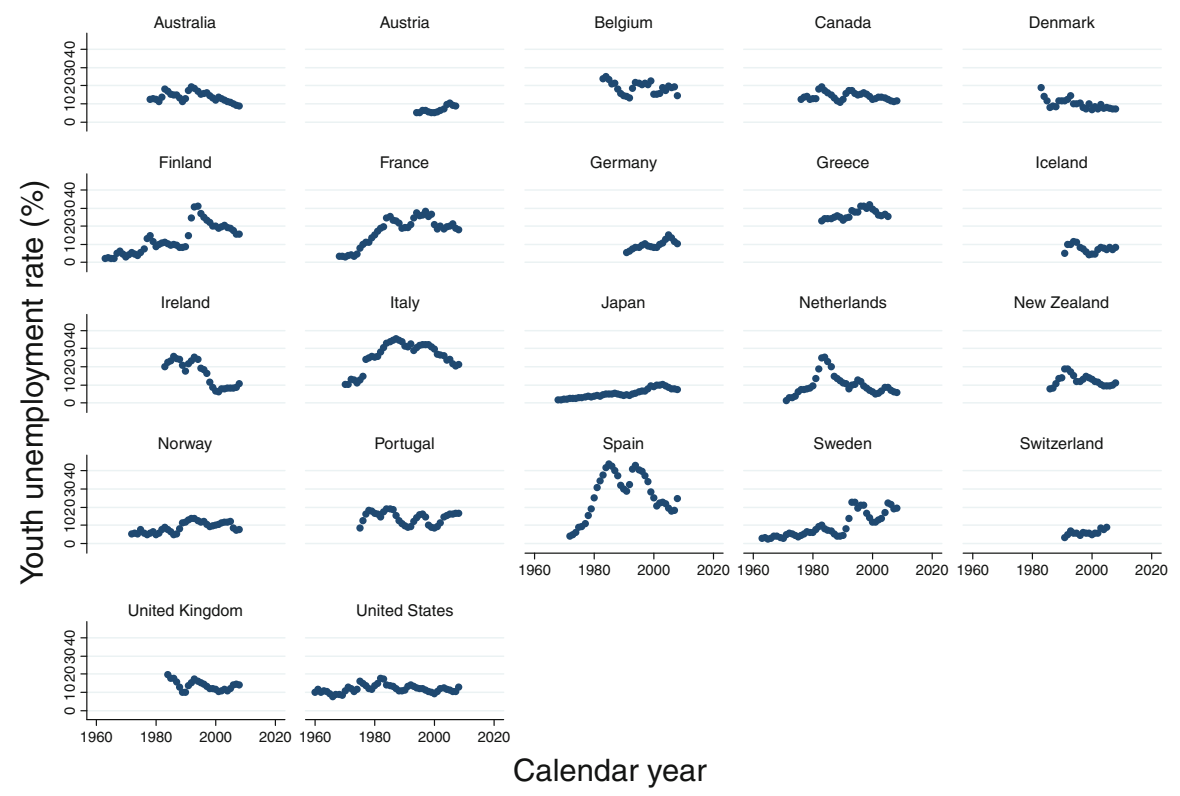

Figure 3 - Youth unemployment rate (15-24 years old). A selection of 22 OECD countries 
evidence presented in Gruber and Wise (2010), based on individual country analyses and a cross-country analysis, shows that an increase in the employment of older persons is associated with an increase in the employment of youth and they conclude this is evidence against the assumption of a fixed lump of labour. ${ }^{4}$

Concerning the latter assumption that older and younger workers are substitutes, economic theory suggests that the more similar the age groups are with respect to skills the greater is the degree of substitution. Some previous studies have identified significant substitutability between workers of different ages but with a considerable variation in the degree of substitution (see Hamermesh 1993, Table 3.9, for an overview). Also, for instance, Card and Lemieux (2001) and Fitzenberger and Kohn (2006) estimate, based on the work of Sato (1967), a structural model using a CES production function and find that workers of different age are imperfect substitutes, while Hebbink (1993) reports a negative elasticity of substitution which suggests that older and younger workers are complements. In line with Hamermesh (2001), one may conclude that the empirical evidence is rather inconclusive concerning the degree of substitution and, furthermore, there is no empirical evidence on a macro-level on the degree of substitution between the groups of workers that our paper is interested in, namely between the potential early retirees age 55-64 (the older workers) and the younger workers age 15-24.

Nowadays policy makers' goals seem to have come around 180 degrees, showing an increasing policy emphasis on discouraging early retirement and increasing employment of older people to counter the economic and fiscal consequences of an aging population. In many OECD countries social security programs and pension schemes are being redesigned to create stronger incentives for continued work at older ages. For instance, while in many countries complete early retirement becomes an increasingly less attractive option, gradual retirement programs have been created for older workers to reduce their hours of work (see, e.g., Kantarci and van Soest 2008). These policy changes may in part explain the rise in employment rates of older men during the second half of the 1990s in many OECD countries, shown in Figure 1 (see footnote 1). As discussed in Gruber and Wise (2010), opponents of such policy changes argue that this increase in employment of older people will adversely affect youth employment. The assumption discussed above that older and younger workers are substitutes, is a crucial one in this discussion. Therefore, and due to the inconclusive empirical evidence on this issue, we revisit the nexus between employment of older and younger workers, if only to put any concerns for adverse effects of later retirement to rest.

4 They provide further empirical evidence against the assumption of a fixed lump of labour by examining the large flows of women into the labour market in the past decades and showing that this appears to have been unrelated to changes in male employment. 
This paper examines empirically to what extent employment of older people aged 55-64 affects the employment of younger people aged 15-24. To be more precise, the aim of the paper is to examine to what extent employment of the young and old are complements or substitutes. Raising employment of older people could reduce employment of the young if they are substitutes and could increase employment of the young if they are complements. The potential effects of an increase in employment of older people on younger workers in an economy range beyond the ways firms or sectors deal with changes in their workforce as there are important secondary effects for the economy as a whole, leading to adjustments in the workforce by other firms and sectors. This makes a comparison of economies over time and across countries a natural base for an empirical analysis. We take such a macro approach and estimate a dynamic model of employment of the young, prime age and older people using panel data of 22 OECD countries over the time period 1960-2008.

As discussed above, the assumption that older and younger workers are substitutes is a necessary condition for job creation for the young by promoting early retirement for older workers but it is not a sufficient condition since the total amount of work to be done in the economy may be affected as well. As mentioned, Gruber and Wise (2010) provide evidence against this latter condition of a fixed lump of labour. Moreover we will show in this paper that there is no empirical support for the necessary condition that younger and older workers are substitutes. If anything, there is some evidence that they are complements. This result suggests that policy changes aimed at increasing employment of older people, such as discouraging early retirement, will have no adverse effects on youth employment.

The outline of the paper is as follows. Section 2 describes the data. Section 3 sets up the empirical model and presents the empirical results. Section 4 concludes.

\section{THE DATA}

For 22 OECD countries we have collected annual data on employment rates of young, prime age and older persons, real wage rates, gross domestic product per capita, consumer price indices, the shares of female employment in total employment, average hours of work per week, and the age composition of the population. The data cover the time period 1960-2008.

Statistics on male and female employment, before tax average wages and population by age groups are taken from the on-line Statistics of the Organization for Economic Co-operation and Development (2010). Employment is defined as the number of persons in paid work or self-employment. Statistics on consumer price indices are taken from the World Bank Development Indicators (2010). International comparable statistics on Gross Domestic 
Product (GDP), annual hours of work and population size have been provided by the Groningen Growth and Development Centre. ${ }^{5}$

We have used publicly available information to go back in time as far as possible. To ensure consistency over time we use only one source for any one data series and do not attempt to link earlier data, if at all possible, from another source. The statistics for Germany were influenced by the reunification of East and West Germany and for this reason only the observations of Germany from 1991 onwards are included. Altogether these years and countries form 686 observations. The panel is unbalanced and Table 1 shows the years of observation for each country.

We distinguish three age groups. The young age group is defined as individuals aged 15 to 24 (both years included), the prime age people are defined as individuals aged 25-54, and the older people are defined as individuals aged 55-64. Table 1 shows the employment rates by age category and country for selected time periods. Table 2 shows for selected time periods the sample means for each country of the main explanatory variables used in the empirical analysis. The wage rate is defined as the average real hourly wage rate and real GDP per capita is in 2009 US dollars. Both these variables are corrected for differences across countries in purchasing power. Hours of work is defined as the average actual working hours per week of the employed population. Not shown in Table 2 are the variables controlling for the demographic composition of each country. For a slightly shorter time period, yearly information on all variables for the 22 countries used in the empirical analysis is presented in Kalwij et al. (2009). Tests for panel unit roots show that most univariate series are non-stationary and that all series in first differences are stationary. ${ }^{6}$

\section{MODEL SPECIFICATION AND ESTIMATION RESULTS}

\subsection{A Dynamic Model of Employment}

The basis of our empirical approach is a dynamic model of labour demand (e.g., Hamermesh 1993). Such a model has been used to estimate dynamic complementarities and substitutions between employment, capital and hours of work, and the speed of adjustment on the labour market (e.g., Hamermesh 1993; Tables 7.4 and 7.8). This model is firm-theory based and assumes

5 The Total Economy Database (2010). The Groningen Growth and Development Centre collects data from the official international statistics.

6 We use the Fisher test as outlined in Maddala and Wu (1999). 


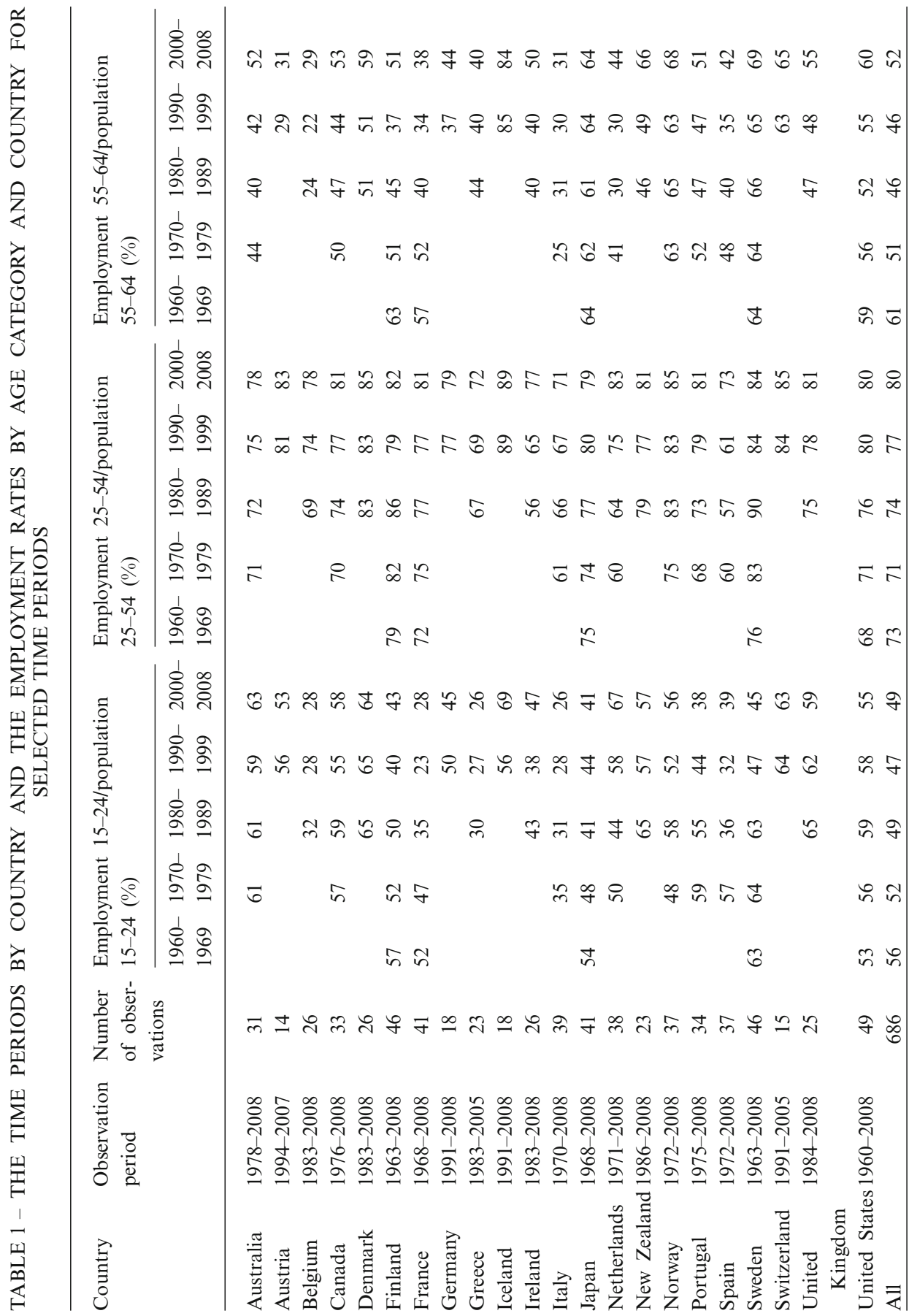




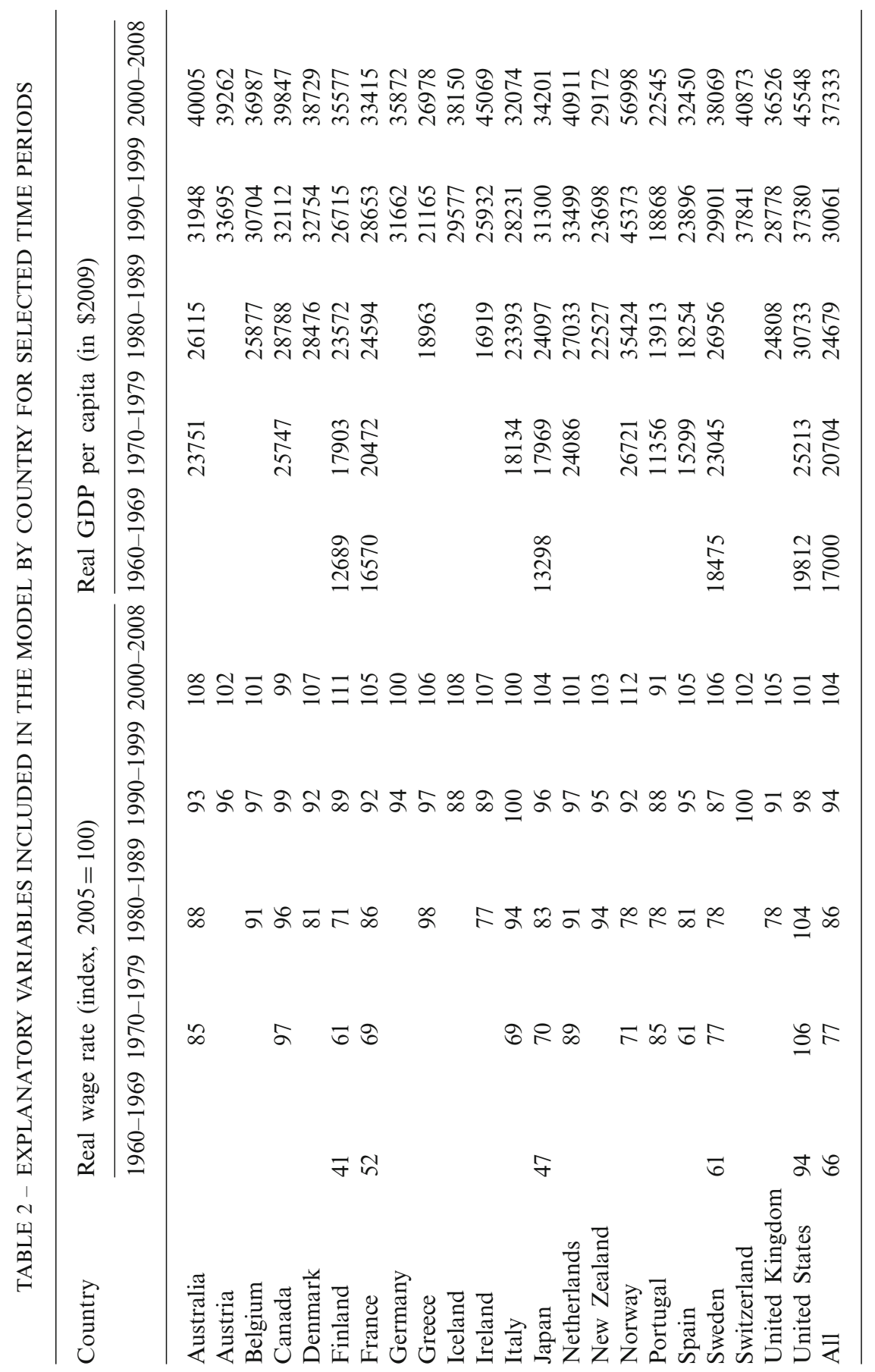




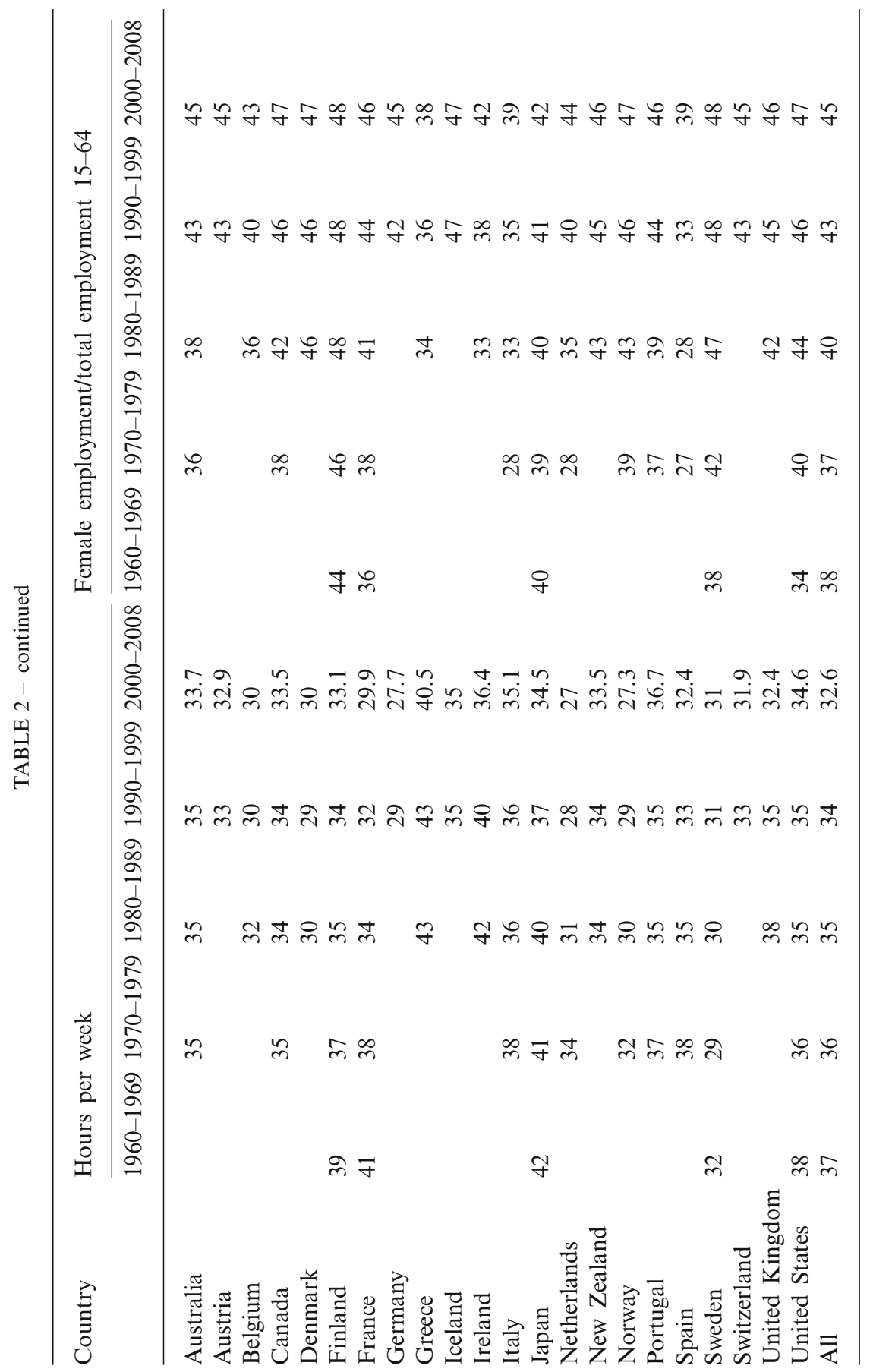


quadratic adjustment costs. ${ }^{7}$ The advantage of such a model is that it can be estimated using country-level data while retaining its theoretical basis.

We consider employment for the three age groups defined in Section 2: the young, prime age, and old. $E_{c t}$ denotes a $(3 \times 1)$-vector containing age group specific employment in country $c$ in year $t$. Demand and supply factors affecting employment are denoted by $X_{c t}$, a $(k \times 1)$-vector. Target employment is denoted by $E_{c t}^{*}$ and relates to demand and supply factors as follows

$$
E_{c t}^{*}=\alpha_{c}+\Phi X_{c t}+u_{c t},
$$

where $\Phi$ is a $(3 \times k)$-matrix containing the parameters of interest, $\alpha_{c}$ is $(3 \times 1)$ vector with country specific intercepts, the time varying demand and supply factors are denoted by $X_{c t}$, and $u_{c t}$ is a vector of random error terms. Changes in demand and supply factors do not immediately yield a new equilibrium and partial adjustment is assumed

$$
E_{c t}-E_{c t-1}=\Gamma\left(E_{c t}^{*}-E_{c t-1}\right)
$$

$\Gamma$ is a $(3 \times 3)$-matrix with adjustment coefficients. Substituting Eq. (1) in (2) yields the following partial adjustment model

$$
E_{c t}=\Lambda E_{c t-1}+\Gamma \alpha_{c}+\Gamma \Phi X_{c t}+\Gamma u_{c t}
$$

where $\Lambda=(I-\Gamma)$ and $I$ is the identity matrix. The long run relationships between employment and the labour demand and supply factors are given by the matrix $\Phi$. Labour market rigidities, for instance, may cause the diagonal elements of the matrix $\Lambda$ to be greater than 0 . The off-diagonal elements of the matrix $\Lambda$ indicate to what extent (dynamic) adjustment in employment in a particular age group takes place due to a change in employment in another age group. Employment for two different age groups are complements when the corresponding off-diagonal element has a positive sign and substitutes if it has a negative sign. We will test whether $\Lambda$ is symmetric and impose it when not rejected. ${ }^{8}$ In the special case that all off-diagonal elements of $\Lambda$ are equal to zero this implies employment adjustment within an age group does not lead to employment adjustment in the other age group and we may in this case as well estimate employment equations for each age group separately.

7 The basic theory assumes that a firm maximizes profits using rational expectations of future prices under quadratic adjustment costs and a quadratic production function (see Hamermesh 1993).

8 Whether $\Lambda$ is symmetric or not depends on the structure of production and the nature of the adjustment costs. A simple example is where both production function and adjustment costs are quadratic and either the matrix of quadratic adjustment costs or the quadratic term in the production function is scalar. 
As discussed in the introduction, we estimate the model outlined above using country level data and this whole-economy approach has the important advantage that it takes into account secondary effects on the economy of changes in employment of people in different age groups. This approach is, however, limited by assuming parameter-constancy across countries. For instance, there may be country differences in the degree of substitution between younger and older worker due to different labour market institutions. We estimate the average substitution effect in the 22 OECD countries. The small numbers of observations for each country prevent a robust analysis by country. To obtain insights into what extent labour market institutions may affect the degree of substitution between younger and older worker we also estimate Eq. (3) for groups of countries that have (arguably) similar labour market institutions. A further limitation is that the model does not identify the causes which make younger and older workers substitutes or complements. Having said this, the model is perfectly suitable for determining whether younger and older workers are, on average, substitutes or complements, and that is what the empirical analysis is set out to do.

The employment variables for each age group are relative to the population aged 15-64. As formalised in Eq. (1), target employment is related to the observed demand and supply factors $X_{c t}$. The factors included in the model are the logarithm of the real wage rate per hour and the logarithm of the real gross domestic product per capita. The logarithmic specification together with the country-specific effects correct for the fact we use wage rate indices rather than real wage rates (see Table 2). In addition, working hours have changed over time, thereby affecting the number of employed people (Kapteyn et al. 2004), and, as also discussed in Gruber and Wise (2010), there has been a strong increase in female labour force participation which may have affected the number of employed people. We take these two trends into account by including the logarithm of average hours of work per week and the share of female employment in total employment. A deterministic time trend is included in all equations. Finally, the distribution of employment over the age groups is affected by the demographic composition of the population and to capture this we include age group specific population shares (ages 1524, 25-54 and 55-64).

As mentioned in Section 2, all variables used in the analysis are nonstationary in levels but stationary in first differences. We therefore estimate Eq. (3) in first differences. This also implies that the country specific fixed effect $\alpha_{c}$ is eliminated and that the model estimates are obtained from within country variation of the variables over time. We estimate the model, i.e. Eq. (3), in two steps. In the first step we estimate each of the three reduced form employment equations of the model using the Instrumental Variable estimator 
proposed by Anderson and Hsiao (1982). ${ }^{9}$ This yields estimates of the parameters $\Lambda, \Gamma$ and $\Gamma \Phi$. We improve upon the efficiency by using an optimal weighting matrix. Most of the explanatory variables discussed above are plausibly endogenous, and in particular the one-period lagged dependent variables, and for this reason all of them are instrumented. Under the assumption of no autocorrelation, all variables in the model that are lagged at least two periods can be used as instruments. We use lags five, four, three, and two. Variables used to form additional instruments are the population shares of individuals under 15 and over 64, and (lagged) unemployment of the population aged 15-64. To validate this choice an over-identification test is carried out to test the null-hypothesis that the instruments and the error term are independent. Furthermore we test for serially uncorrelated error terms. The model is estimated in first differences and the null-hypothesis of the autocorrelation test is that there is no second order autocorrelation in the first-differenced error term. In the second step we use a Minimum Distance Estimator to obtain estimates of the structural parameters $\Lambda$ and $\Phi$ (see, e.g., Kodde et al. 1990).

\subsection{Estimation Results}

Table 3 reports the estimation results of the model outlined in Section 3.1. Before turning to the estimation results we briefly discuss the model specification tests reported in the bottom panel of Table 3. In the discussion below we adopt a $5 \%$ level of significance. The three over-identification tests, one for each reduced form employment equation, do not reject exogeneity of our instruments. ${ }^{10}$ The three autocorrelation tests each do not reject the null of no serial correlation.

Concerning the control variables, Table 3 shows that the effects of the wage rate and GDP per capita are as expected, though not all wage effects are statistically significant. An increase in the wage rate results in a decrease in employment, while economic growth is good for employment. An increase in the (age specific) population results in an increase in employment. The share of female employment has insignificant effects on the employment of younger and prime age people and a significant negative effect on employment of older people, which may indicate a (minor) substitution of older workers with female workers. An increase in the hours of work per week results in a significant increase in employment for the younger people.

9 See Bond (2002) for a review of estimators for dynamic panel data models.

10 We have also tested whether or not the instruments have sufficient explanatory power (see Bound et al. 1995). In the first stage regressions the partial F-test statistics all have p-values that are virtually zero. 
TABLE 3 - ESTIMATION RESULTS OF EQ.

\begin{tabular}{|c|c|c|c|c|c|c|}
\hline \multirow[t]{2}{*}{ Dependent variable } & \multicolumn{2}{|c|}{$\begin{array}{l}\text { Younger people } \\
\text { Employment } \\
\text { 15-24/population } \\
15-64\end{array}$} & \multicolumn{2}{|c|}{$\begin{array}{l}\text { Prime age people } \\
\text { Employment } \\
25-54 / \text { population } \\
15-64\end{array}$} & \multicolumn{2}{|c|}{$\begin{array}{l}\text { Older people } \\
\text { Employment } \\
\text { 55-64/population } \\
15-64\end{array}$} \\
\hline & Estimate & $t$-Value & Estimate & $t$-Value & Estimate & $t$-Value \\
\hline $\begin{array}{l}\Lambda \text {, symmetry imposed } \\
\text { Employment } 15-24 /\end{array}$ & $0.298 * *$ & 2.97 & 0.107 & 1.62 & 0.000 & 0.01 \\
\hline $\begin{array}{l}\text { population } 15-64, t-1 \\
\text { Employment } 25-54 / \\
\text { population } 15-64, t-1\end{array}$ & 0.107 & 1.62 & $0.368^{* *}$ & 4.66 & $0.054^{*}$ & 1.91 \\
\hline $\begin{array}{l}\text { Employment } 55-64 / \\
\text { population } 15-64, t-1 \\
\text { Long-run effects, } \Phi\end{array}$ & 0.000 & 0.01 & $0.054^{*}$ & 1.91 & $0.559^{* *}$ & 6.50 \\
\hline Population (age group specific) & $0.877^{* *}$ & 4.29 & $0.566^{* *}$ & 3.15 & $0.799 * *$ & 5.50 \\
\hline Ln(real hourly wage rate) & $-0.084^{* *}$ & -2.39 & $-0.093^{*}$ & -1.81 & -0.031 & -1.19 \\
\hline $\operatorname{Ln}(G D P)$ & $0.209^{* *}$ & 5.63 & $0.328 * *$ & 5.94 & $0.057 * *$ & 2.08 \\
\hline $\mathrm{Ln}$ (hours of work per week) & $0.223^{* *}$ & 2.35 & 0.161 & 1.14 & 0.030 & 0.43 \\
\hline Share female employment & -0.193 & -1.16 & 0.402 & 1.65 & $-0.277 * *$ & -2.26 \\
\hline Goodness of fit, $\mathrm{R}^{2}$ & 0.22 & & 0.47 & & 0.53 & \\
\hline Over Identification test ( $p$-value) & 0.18 & & 0.19 & & 0.19 & \\
\hline Autocorrelation test ( $p$-value) & 0.76 & & 0.06 & & 0.24 & \\
\hline Number of countries & 22 & & 22 & & 22 & \\
\hline Number of observations & 576 & & 576 & & 576 & \\
\hline Test of symmetry of $\Lambda$ ( $p$-value) & 0.20 & & & & & \\
\hline
\end{tabular}

** Significant at a $5 \%$ level; * significant at a $10 \%$ level

Of main interest for this paper are the estimates of $\Lambda$ in the top panel of Table 3. Based on the test statistic at the bottom of Table 3 we do not reject symmetry of the matrix $\Lambda$. The diagonal elements are positive and individually significant. The estimates of the diagonal elements indicate lower labour market rigidity for the younger workers compared to older workers. The offdiagonal elements are positive and jointly significant. ${ }^{11}$ These results do not support the hypothesis that employment of younger and older people are substitutes and even suggest some minor complementarities of employment in the different age categories. An increase in employment of older people with one worker yields an additional 0.054 prime age worker.

\subsection{A Sensitivity Analysis: the Role of Labour Market Institutions and Social Policies}

Labour market institutions and social policies may affect the degree of substitution between older and younger workers, i.e. the $\Lambda$ parameters. For instance,

11 The p-value is equal to 0.001 for testing the null-hypothesis that all off-diagonal elements are equal to zero. 
policymakers and unions may have played a role in the extent to which older people who retire and leave the labour force are replaced by younger people. We examine this by estimating our model for groups of countries in which we classify countries according to their labour market institutions and social policies. The way to classify countries is, however, not a trivial issue. For instance, Calmfors and Driffill (1988) argue that here is a hump-shape relationship between the degree of centralization of wage setting and real wages, and they challenge the notion that the more 'corporatist' is an economy the better is its economic performance. Their results show that real wages are lowest at the extremes of the degree of centralization and that at these extremes economic performance in terms of employment may be highest. Freeman (2008), however, argues that this hump-shape has since disappeared but, more importantly, argues that it is very hard to show that labour market institutions improve or worsen economic performance. One reason for this may be that the effect of institutions is likely to have changed over the last decades. Different economic circumstances may ask for different types of institutions. At best, he argues, labour market institutions (or the degree of centralization of wage setting) reduce wage or income inequality. This latter notion is also present in a 'social model' classification of Sapir (2006) and in this section we take his approach.

Sapir (2006) proposes two criteria to evaluate the different social models that (may) lead to different macro economic performances: (i) efficiency, that is, whether the model provides the incentives so as to achieve the highest employment rate, and (ii) equity, that is, whether the social model achieves a relatively low poverty risk. Based on this idea we classify our 22 countries in four types of social models. Details of our classification are in the Appendix. The first type is the Nordic model which is characterized by a high employment rate and low income inequality. The second type is the Anglo-Saxon model that is often described, also in the abovementioned papers, as the opposite of the Nordic model in terms of labour market institutions. Despite this, the Anglo-Saxon model is as well characterized by a high employment rate but also, in contrast to the Nordic model, by high income inequality. Continental countries, the third social model, are characterized by low income inequality but at the expense of a low employment rate. The Mediterranean social model appears to perform worst in terms of employment and equity and is characterized by high income inequality and a low employment rate.

As discussed above, the type of social model may affect the degree of substitution between older and younger workers, i.e. the $\Lambda$ parameters. The estimates of $\Lambda$ by social model are in Table 4. For each social model we do not find support for the hypothesis that employment of younger and older people are substitutes. The results suggest, in line with our conclusion in Section 3.2, 
TABLE 4 - A SENSITIVITY ANALYSIS: ESTIMATES OF $\Lambda$ OF EQ. (3) BY SOCIAL MODEL

\begin{tabular}{|c|c|c|c|c|c|c|}
\hline \multirow[t]{2}{*}{ Dependent variable } & \multicolumn{2}{|c|}{$\begin{array}{l}\text { Younger people } \\
\text { Employment15- } \\
\text { 24/population } \\
\text { 15-64 }\end{array}$} & \multicolumn{2}{|c|}{$\begin{array}{l}\text { Prime age people } \\
\text { Employment } \\
25-54 / \text { population } \\
15-64\end{array}$} & \multicolumn{2}{|c|}{$\begin{array}{l}\text { Older people } \\
\text { Employment } \\
\text { 55-64/population } \\
\text { 15-64 }\end{array}$} \\
\hline & Estimate & $t$-Value & Estimate & $t$-Value & Estimate $t$ & $t$-Value \\
\hline \multicolumn{7}{|l|}{ Nordic countries } \\
\hline $\begin{array}{l}\text { Employment } \\
\text { 15-24/ } \\
\text { population } \\
15-64, \mathrm{t}-1\end{array}$ & 0.163 & 1.22 & $0.182^{* *}$ & 1.96 & $0.088^{*}$ & 1.91 \\
\hline $\begin{array}{l}\text { Employment } \\
25-54 / \\
\text { population } \\
15-64, \mathrm{t}-1\end{array}$ & $0.182^{* *}$ & 1.96 & $0.253^{* *}$ & 2.26 & -0.003 & -0.08 \\
\hline $\begin{array}{l}\text { Employment } \\
55-64 / \\
\text { population } \\
15-64, \mathrm{t}-1\end{array}$ & $0.088^{*}$ & 1.91 & -0.003 & -0.08 & 0.110 & 1.04 \\
\hline Anglo-Saxon countries & & & & & & \\
\hline $\begin{array}{l}\text { Employment } \\
\text { 15-24/population } \\
15-64, \mathrm{t}-1\end{array}$ & $0.282^{* *}$ & 2.75 & $0.127^{* *}$ & 2.05 & 0.056 & 1.19 \\
\hline $\begin{array}{l}\text { Employment } \\
25-54 / \\
\text { population } \\
15-64, \mathrm{t}-1\end{array}$ & $0.127^{* *}$ & 2.05 & $0.398^{* *}$ & 4.72 & $0.072^{* *}$ & 2.23 \\
\hline $\begin{array}{l}\text { Employment } \\
55-64 / \\
\text { population } \\
15-64, \mathrm{t}-1\end{array}$ & 0.056 & 1.19 & $0.072^{* *}$ & 2.23 & $0.317^{* *}$ & 2.52 \\
\hline Continental countries & & & & & & \\
\hline $\begin{array}{l}\text { Employment } \\
15-24 / \\
\text { population } \\
15-64, \mathrm{t}-1\end{array}$ & $0.386^{* *}$ & 3.98 & 0.025 & 0.46 & 0.057 & 0.97 \\
\hline $\begin{array}{l}\text { Employment } \\
25-54 / \\
\text { population } \\
15-64, \mathrm{t}-1\end{array}$ & 0.025 & 0.46 & $0.476^{* *}$ & 6.38 & 0.001 & 0.03 \\
\hline
\end{tabular}


TABLE 4 - continued

\begin{tabular}{|c|c|c|c|c|c|c|}
\hline \multirow[t]{2}{*}{ Dependent variable } & \multicolumn{2}{|c|}{$\begin{array}{l}\text { Younger people } \\
\text { Employment15- } \\
\text { 24/population } \\
\text { 15-64 }\end{array}$} & \multicolumn{2}{|c|}{$\begin{array}{l}\text { Prime age people } \\
\text { Employment } \\
25-54 \text { /population } \\
15-64\end{array}$} & \multicolumn{2}{|c|}{$\begin{array}{l}\text { Older people } \\
\text { Employment } \\
55-64 / \text { population } \\
15-64\end{array}$} \\
\hline & Estimate & $t$-Value & Estimate & $t$-Value & Estimate $t$ & $t$-Value \\
\hline $\begin{array}{l}\text { Employment } \\
55-64 / \\
\text { population } \\
15-64, \mathrm{t}-1\end{array}$ & 0.057 & 0.97 & 0.001 & 0.03 & $0.702^{* *}$ & 5.36 \\
\hline Mediterranean countries & & & & & & \\
\hline $\begin{array}{l}\text { Employment } \\
\text { 15-24/ } \\
\text { population } \\
15-64, \mathrm{t}-1\end{array}$ & $0.582^{* *}$ & 4.44 & -0.033 & -0.46 & -0.004 & -0.07 \\
\hline $\begin{array}{l}\text { Employment } \\
25-54 / \\
\text { population } \\
15-64, \mathrm{t}-1\end{array}$ & -0.033 & -0.46 & $0.288^{* *}$ & 3.47 & $0.155^{* *}$ & 3.84 \\
\hline $\begin{array}{l}\text { Employment } \\
55-64 / \\
\text { population } \\
15-64, \mathrm{t}-1\end{array}$ & -0.004 & -0.07 & $0.155^{* *}$ & 3.84 & $0.350^{* *}$ & 3.23 \\
\hline
\end{tabular}

See Appendix for social model classification of the 22 countries ** Significant at a $5 \%$ level; * significant at a $10 \%$ level

that there are some minor complementarities of employment in the different age categories, except for continental countries.

\section{CONCLUSIONS}

Our empirical analysis does not support the hypothesis that employment of the young and old are substitutes and finds some minor complementarities of employment in the different age groups. Changes in employment of older people aged 55-64 have, on average, small but positive effects on employment of the younger people aged 15-24 and on the prime age people aged 25-54. As discussed by Acemoglu (2002), the last half century has been characterized by a continuing growth in the level of skill of new workers, type of skill requirements, and technological change that has been skill biased. This may have resulted in groups of younger and older worker that are very poor substitutes. 
From a policy point of view these findings suggest that the policies during the 1970s and 1980s aimed at facilitating early retirement have been ineffective as instruments for reducing youth unemployment. These findings also suggests that the u-turn of policy makers since the mid 1990s to redesign social security programs and pension schemes to create stronger incentives for continued work at older ages will have no adverse effects on youth employment. Finally, with the current economic crisis, youth unemployment is increasing substantially in many countries and this will put pressure on government to act, perhaps by re-introducing early retirement programs. According to the analysis presented, this could be counterproductive.

Acknowledgements We wish to thank seminar participants at the Utrecht School of Economics and the International Social Security program meetings of the National Bureau of Economic Research in Barcelona, Spain, 18-21 May 2006, and in Taormina, Italy, 24-26 May 2007, and two anonymous referees for valuable comments and Lisa Klautzer for research assistance. For financial support we wish to thank the National Bureau of Economic Research (Cambridge, USA), NETSPAR and Stichting Instituut GAK.

Open Access This article is distributed under the terms of the Creative Commons Attribution Noncommercial License which permits any noncommercial use, distribution, and reproduction in any medium, provided the original author(s) and source are credited.

\section{APPENDIX: SOCIAL MODELS}

We follow the classification of Sapir (2006). Efficiency is measured with the employment rate and equity is measured with the Gini coefficient. The

TABLE - A1

\begin{tabular}{llllll}
\hline Country & $\begin{array}{l}\text { Employment } \\
\text { rate }\end{array}$ & $\begin{array}{l}\text { Gini } \\
\text { coefficient }\end{array}$ & $\begin{array}{l}\text { Employment } \\
\text { rate }\end{array}$ & $\begin{array}{l}\text { Gini } \\
\text { coefficient }\end{array}$ & Social model \\
\hline Iceland & 82.8 & 24.0 & High & Low & Nordic \\
Denmark & 76.0 & 24.7 & High & Low & Nordic \\
Sweden & 73.5 & 25.0 & High & Low & Nordic \\
Norway & 75.6 & 25.8 & High & Low & Nordic \\
Netherlands & 72.0 & 30.9 & High & Low & Nordic \\
Canada & 72.5 & 33.1 & High & High & Anglo-Saxon \\
Switzerland & 77.4 & 33.1 & High & High & Anglo-Saxon \\
Australia & 70.3 & 35.2 & High & High & Anglo-Saxon \\
United Kingdom & 72.7 & 36.0 & High & High & Anglo-Saxon \\
New Zealand & 73.5 & 36.2 & High & High & Anglo-Saxon \\
United States & 71.2 & 40.8 & High & High & Anglo-Saxon \\
\hline
\end{tabular}


TABLE - A1 continued

\begin{tabular}{llllll}
\hline Country & $\begin{array}{l}\text { Employment } \\
\text { rate }\end{array}$ & $\begin{array}{l}\text { Gini } \\
\text { coefficient }\end{array}$ & $\begin{array}{l}\text { Employment } \\
\text { rate }\end{array}$ & $\begin{array}{l}\text { Gini } \\
\text { coefficient }\end{array}$ & Social model \\
\hline Japan & 68.7 & 24.9 & Low & Low & Continental \\
Belgium & 60.5 & 25.0 & Low & Low & Continental \\
Finland & 67.2 & 26.9 & Low & Low & Continental \\
Germany & 65.0 & 28.3 & Low & Low & Continental \\
Austria & 67.8 & 30.0 & Low & Low & Continental \\
Spain & 62.0 & 32.5 & Low & High & Mediterranean \\
France & 62.4 & 32.7 & Low & High & Mediterranean \\
Greece & 59.6 & 35.4 & Low & High & Mediterranean \\
Ireland & 65.5 & 35.9 & Low & High & Mediterranean \\
Italy & 57.4 & 36.0 & Low & High & Mediterranean \\
Portugal & 67.8 & 38.5 & Low & High & Mediterranean \\
\hline
\end{tabular}

employment rate is defined as total employment over the population age 1564. The employment rates and Gini coefficients are measured in 2004 or 2005. An employment rate above the Lisbon target of $70 \%$ is considered high and a Gini coefficient above the EU average of 31 is considered high (see Table A1).

\section{REFERENCES}

Acemoglu, D. (2002), 'Technical Change, Inequality, and Labor Market', Journal of Economic Literature, XL, pp. 7-72.

Anderson, T.W. and C. Hsiao (1982), 'Formulation and Estimation of Dynamic Models Using Panel Data', Journal of Econometrics, 18, pp. 47-72.

Bond, S.R. (2002), 'Dynamic Panel Data Models: A Guide to Micro Data Methods and Practice', Portuguese Economic Journal, 1, pp. 141-162.

Bound, J., D.A. Jaeger and R.M. Baker (1995), 'Problems with Instrumental Variables Estimation When The Correlation Between the Instruments and the Endogenous Explanatory Variable is Weak', Journal of the American Statistical Association, 90, pp. 443-450.

Calmfors, L. and J. Driffill (1988), 'Centralization of Wage Bargaining', Economic Policy, 3(6), pp. 13-61.

Card, D. and T. Lemieux (2001), 'Can Falling Supply Explain The Rising Return to College for Younger Men? A Cohort-Based Analysis', The Quarterly Journal of Economics, 116, pp. 705746.

Fitzenberger, B. and K. Kohn, (2006), 'Skill Wage Premia, employment, and Cohort Effects: Are Workers in Germany All of the Same Type', Centre for European Economic Research (ZEW), Discussion Paper No. 06-044. 
Freeman, R.B. (2008), 'Labor Market Institutions Around the World, Centre for Economic Performance', CEP Discussion Paper No. 844.

Gruber, J. and D.A. Wise (2004), Social Security Programs and Retirement Around the World: Micro-Estimation. National Bureau of Economic Research, The University of Chicago Press, Chicago.

Gruber, J. and D.A. Wise (2010), Social Security Programs and Retirement Around the World: The Relationship to Youth Employment. Chicago University Press, Chicago.

Hamermesh, D.S. (1993), Labor Demand. Princeton University Press, Princeton, New Jersey.

Hamermesh, D.S. (2001), Older Workers in the Coming Labor "Shortage": Implications of Labour Demand, Prepared for a Roundtable on the Demand for Older Workers, The Brookings Institution, 23 March.

Hamermesh, D.S. and G.A. Pfann (1996), 'Adjustment Costs in Factor Demand', Journal of Economic Literature, XXXIV, pp. 1264-1292.

Hebbink, G.E. (1993), 'Production Factor Substitution and Employment by Age Group', Economic Modelling, 10, pp. 217-224.

Kalwij, A., A. Kapteyn and K. de Vos (2009), 'Early Retirement and Employment of the young, Networks for Studies on Pensions, Aging and Retirement', Discussion Paper 03/2009-012.

Kantarci, T. and A. van Soest (2008), 'Gradual Retirement: Preferences and Limitation', De Economist, 156, pp. 113-144.

Kapteyn, A., A. Kalwij and A. Zaidi, 2004, The Myth of Worksharing, Labour Economics, 11, pp. 293-313.

Kodde, D.A., F.C. Palm and G.A. Pfann (1990), Asymptotic Least-Squares Estimation Efficiency Considerations and Applications', Journal of Applied Econometrics, 5, pp. 229-243.

Maddala, G.S. and S. Wu (1999), A Comparative Study of Unit Root Tests with Panel Data and a New Simple Test, Oxford Bulletin of Economics and Statistics, Special Issue, 61, pp. 631-652.

Organization for Economic Co-operation and Development (2010), Statistics, http://stats.oecd.org/.

Sapir, A. (2006), 'Globalisation and the Reform of European Social Models', Journal of Common Market Studies, 44(2), pp. 369-390.

Sato, K. (1967), 'A Two-Level Constant-Elasticity-of-Substitution Production Function', Review of Economic Studies, 34, pp. 201-218.

Total Economy Database (2010), Groningen Growth \& Development Centre, University of Groningen, http://www.ggdc.net/dseries/totecon.shtml.

Van Dalen, A.P. and K. Henkens (2002), 'Early-Retirement Reform: Can it and Will it Work?', Ageing \& Society, 22, pp. 209-231.

World Bank Development Indicators (2010), http://data.worldbank.org/. 